\title{
Energy utilization of light and heavy weaned piglets subjected to different dietary energy levels
}

\author{
Andréa Machado Leal Ribeiro ${ }^{1}$, Giovani Farina ${ }^{1}$, Marcia de Souza Vieira ${ }^{1}$, Valentino Arnaiz \\ Perales $^{1}$, Alexandre de Mello Kessler ${ }^{1}$
}

\footnotetext{
${ }^{1}$ Universidade Federal do Rio Grande do Sul, Departamento de Zootecnia, Porto Alegre, RS, Brazil.
}

ABSTRACT - This study was conducted to evaluate the effects of dietary metabolisable energy (ME: 3.25, 3.40, 3.55,

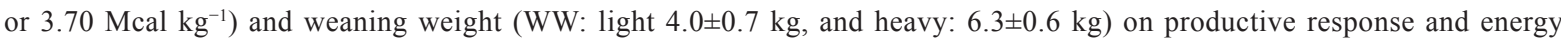
utilization of weaned piglets. Sixty-four male piglets were housed in 32 metabolic cages (two animals per cage) during the first 14 d postweaning. At day 15, only one animal per cage was kept until day 28. Body composition, energy, and nutrient deposition rates and energy utilization efficiency were measured through a comparative slaughter procedure. Piglets with light WW had a poorer feed conversion ratio and lower weight gain and feed intake when expressed per live weight. Increased ME led to greater daily fat deposition in the empty bodies (defined as weighted mean of the carcass + organs + blood, no intestinal content), while light WW piglets had a reduced protein deposition. Light WW piglets increased heat production with increased ME, but no effect was seen for the heavy WW piglets. By contrast, heavy WW piglets increased empty body gross energy as ME increased, while no influence was observed on light WW piglets. Increasing dietary energy levels did not contribute to the subsequent growth performance of piglets that were lighter at weaning. The lack of interaction between weaning weight and dietary ME content on growth performance does not support the hypothesis that light piglets at weaning do not exhibit compensatory growth because of limitations in energy intake.

Key Words: metabolism, pig nutrition, protein:energy ratio, tissue deposition

\section{Introduction}

It is generally assumed that the young pig up to about $70 \mathrm{~kg}$ body weight (BW) displays a limited physical capacity to ingest nutrients (Quiniou et al., 2000), and will respond to increases in dietary energy concentration with an increase in growth rate during an energy-dependent phase of growth. This phase is believed to extend up to $90 \mathrm{~kg} \mathrm{BW}$; however, the greatest limitation to ingest nutrients occurs in weaned pigs up to about $25 \mathrm{~kg} \mathrm{BW}$ (Campbell, 1987; Whittemore, 1993). Such a limitation has been suggested to prevent the weaned pig from achieving its genetic capacity for growth, especially protein deposition (Van Lunen and Cole, 1998).

Furthermore, the intensive selection pressure to increase the number of piglets born per sow per year led to an increase in the number of stillborn piglets and to

Received January 22, 2016 and accepted June 27, 2016.

Corresponding author: aribeiro@ufrgs.br

http://dx.doi.org/10.1590/S1806-92902016000900005

Copyright (C) 2016 Sociedade Brasileira de Zootecnia. This is an Open Access article distributed under the terms of the Creative Commons Attribution License (http://creativecommons.org/licenses/by/4.0/), which permits unrestricted use, distribution, and reproduction in any medium, provided the original work is properly cited. low birth weight (Fix et al., 2010). Light pigs at weaning seldom show compensatory growth in subsequent rearing phases (Beaulieu et al., 2010; Bérard et al., 2008), and usually require more days to reach market weight. This lack of compensatory growth is because of a combination of factors that compromise the ability of those piglets to reach the same performance results compared with piglets weaned at heavier weights.

Thus, elevated nutritional levels are needed to optimize growth performance in this phase (Trindade Neto et al., 2010). An increase in dietary energy content would be expected to increase energy intake and weight gain. Nevertheless, though it has been tested in previous studies (Oresanya et al., 2008; Vieira et al., 2015), this hypothesis has not been confirmed with the measurement of growth performance responses. Studies with growing pigs have demonstrated an increase in the fat:protein deposition ratio with increasing dietary energy (Souza et al., 2000). However, the literature reveals a paucity of information regarding this effect in recently weaned piglets. The objective of the present study was to evaluate the effect of dietary energy concentration and weaning weight on performance and body composition of weaned piglets to determine if there is any interaction between these factors. 


\section{Material and Methods}

The experiment was conducted in Porto Alegre, RS, Brazil. All procedures used in this experiment were approved by the Ethics Committee in Animal Use of Universidade Federal do Rio Grande do Sul.

Sixty-four weanling barrows (19-21 d of age) of the hybrid strain Agroceres PIC ${ }^{\circledR}$ were allotted to 32 metal metabolic cages $\left(0.48 \mathrm{~m}^{2}\right)$ in two rooms (block) with 16 cages each. They were assigned to weaning weight (WW; light: $4.0 \pm 0.7 \mathrm{~kg}$, and heavy: $6.3 \pm 0.6 \mathrm{~kg}$ ) and metabolisable energy (ME: $3.25,3.40,3.55$, or $3.70 \mathrm{Mcal} \mathrm{kg}^{-1}$ ) groups in a $2 \times 4$ factorial arrangement in a generalised randomised block design. Each treatment had four replications, and each cage was defined as a replication. The experiment was conducted in two nursery periods: pre-starter, between 1 and $14 \mathrm{~d}$ after weaning, and starter, between 15 and $28 \mathrm{~d}$ after weaning. Two animals were placed in each cage in the pre-starter phase for faster adaptation to the feeding and drinking system. For the starter period, the second piglet was removed due to the limited space in the cages.
Consequently, in the pre-starter period, the average daily feed intake (ADFI) is expressed as an average of two pigs. Piglets were given water and feed ad libitum throughout the entire experimental period. Animals were allotted to environmentally controlled rooms, with a temperature of 28 to $32{ }^{\circ} \mathrm{C}$ and 27 to $30{ }^{\circ} \mathrm{C}$ for the pre-starter and starter periods, respectively.

Diets with four ME levels were formulated (3.25, 3.40, 3.55, and $3.70 \mathrm{Mcal} \mathrm{kg}^{-1}$ ) by using increasing levels of full-fat micronised soybeans as a substitute for soybean meal and fed as mash (Table 1). Kaolin was added to the soybean meal (the amount added was approximately 3,2 and $1 \%$ for the ME levels of 3.25, 3.40, and 3.55 Mcal kg-1, respectively) to deliver the same amount of crude protein as the micronised soybeans. Except for ME, the nutritional compositions of the experimental diets were close to the recommended standards (Rostagno et al., 2005). Piglets were given a pre-starter diet during the first $14 \mathrm{~d}$ and a starter diet during the subsequent $14 \mathrm{~d}$ of the experiment. During the manufacture of feeds, five samples of each diet were collected, pooled, mixed, and sampled to achieve $500 \mathrm{~g}$ of

Table 1 - Composition of experimental diets (as-fed basis)

\begin{tabular}{|c|c|c|c|c|c|c|c|c|}
\hline \multirow{2}{*}{ Item } & \multicolumn{4}{|c|}{ Pre-starter ${ }^{1}$} & \multicolumn{4}{|c|}{ Starter $^{1}$} \\
\hline & 3.25 & 3.40 & 3.55 & 3.70 & 3.25 & 3.40 & 3.55 & 3.70 \\
\hline \multicolumn{9}{|l|}{ Ingredient $\left(\mathrm{g} \mathrm{kg}^{-1}\right)$} \\
\hline Corn & 434.0 & 434.0 & 434.0 & 434.0 & 515.0 & 515.0 & 515.0 & 515.0 \\
\hline Soybean meal + kaolin ${ }^{2}$ & 265.0 & 176.0 & 88.0 & 0.0 & 275.0 & 182.0 & 93.0 & 0.0 \\
\hline Micronized soybean & 0.0 & 88.0 & 176.7 & 264.8 & 0.0 & 93.8 & 182.6 & 275.6 \\
\hline Whey & 171.5 & 171.5 & 171.5 & 171.5 & 114.0 & 114.0 & 114.0 & 114.0 \\
\hline Dicalcium phosphate & 11.8 & 12.2 & 12.5 & 12.4 & 12.9 & 12.5 & 12.8 & 12.8 \\
\hline Limestone & 6.4 & 6.4 & 6.0 & 6.0 & 7.9 & 7.5 & 7.4 & 7.4 \\
\hline Min. vit. premix ${ }^{3}$ & 1.5 & 1.5 & 1.5 & 1.5 & 1.5 & 1.5 & 1.5 & 1.5 \\
\hline Other ingredients ${ }^{4}$ & 109.8 & 109.8 & 109.8 & 109.8 & 73.7 & 73.7 & 73.7 & 73.7 \\
\hline \multicolumn{9}{|l|}{ Nutritional composition } \\
\hline \multicolumn{9}{|l|}{ Calculated } \\
\hline ME (Mcal kg $\left.{ }^{-1}\right)$ & 3.25 & 3.40 & 3.55 & 3.70 & 3.25 & 3.40 & 3.55 & 3.70 \\
\hline $\mathrm{Ca}\left(\mathrm{g} \mathrm{kg}^{-1}\right)$ & 7.5 & 7.5 & 7.5 & 7.5 & 7.4 & 7.4 & 7.4 & 7.5 \\
\hline Available P $\left(\mathrm{g} \mathrm{kg}^{-1}\right)$ & 5.0 & 5.0 & 5.0 & 5.0 & 4.3 & 4.3 & 4.3 & 4.3 \\
\hline Dig. lysine $\left(\mathrm{g} \mathrm{kg}^{-1}\right)$ & 14.5 & 14.5 & 14.5 & 14.5 & 12.4 & 12.4 & 12.4 & 12.4 \\
\hline Dig. methionine $\left(\mathrm{g} \mathrm{kg}^{-1}\right)$ & 5.8 & 5.8 & 5.8 & 5.8 & 4.8 & 4.8 & 4.8 & 4.8 \\
\hline Dig. met. + cys. $\left(\mathrm{g} \mathrm{kg}^{-1}\right)$ & 8.7 & 8.7 & 8.7 & 8.7 & 7.7 & 7.7 & 7.7 & 7.7 \\
\hline Dig. threonine $\left(\mathrm{g} \mathrm{kg}^{-1}\right)$ & 9.2 & 9.2 & 9.2 & 9.2 & 7.8 & 7.8 & 7.8 & 7.8 \\
\hline Dig. tryptophan $\left(\mathrm{g} \mathrm{kg}^{-1}\right)$ & 2.6 & 2.6 & 2.6 & 2.6 & 2.2 & 2.2 & 2.2 & 2.2 \\
\hline \multicolumn{9}{|l|}{ Analysed } \\
\hline $\mathrm{ME}^{5}\left(\mathrm{Mcal} \mathrm{kg}^{-1}\right)$ & 3.21 & 3.40 & 3.55 & 3.72 & 3.28 & 3.45 & 3.66 & 3.87 \\
\hline Crude protein $\left(\mathrm{g} \mathrm{kg}^{-1}\right)$ & 210.0 & 210.0 & 210.0 & 210.0 & 190.0 & 190.0 & 190.0 & 190.0 \\
\hline Fat $\left(\mathrm{g} \mathrm{kg}^{-1}\right)$ & 28.0 & 49.5 & 70.0 & 92.0 & 28.0 & 49.5 & 72.0 & 84.0 \\
\hline
\end{tabular}

ME - metabolisable energy.

${ }^{1}$ Pre-starter diet - 1 to $14 \mathrm{~d}$ after weaning; starter diet - 15 to $28 \mathrm{~d}$ after weaning.

${ }^{2}$ Total kaolin added was approximately 3,2 and $1 \%$ for the ME levels of $3.25,3.40$, and $3.55 \mathrm{Mcal} / \mathrm{kg}$, respectively

${ }^{3}$ Content per kg: Fe - 80,000 mg; Cu - 12,000 mg; Mn - 70,000 mg; Zn - 100,000 mg; I - 1,000 mg; Se - 120 mg; vit. A - 2,250,000 IU; vit. D3 - 450,000 IU; vit. E - 4,500 IU; vit. K3 - $400 \mathrm{mg}$; vit. B1 - $350 \mathrm{mg}$; vit. B2 - 1,000 mg; vit. B6 - $350 \mathrm{mg}$; vit. B12 - 4,500 $\mu$ g; niacin - 7,500 mg; pantothenic acid - 4,000 mg; folic acid - 100 mg; biotin - $25 \mathrm{mg}$; antioxidant $-25,000 \mathrm{mg}$

${ }^{4}$ Pre-starter $\left(\mathrm{g} \mathrm{kg}^{-1}\right)$ : swine plasma - 40.0; sugar - 30.0; corn gluten meal - 20.0; L-lysine HCL - 4.2; acidifier - 4.0; DL-methionine - 3.2; Zn oxide - 4.0; L-threonine - 1.6; salt - 1.0; flavouring agent - 1.0; choline chloride (60\%) - 0.7; L-tryptophan - 0.1. Starter $\left(\mathrm{g} \mathrm{kg}^{-1}\right)$ : sugar - 30.0; corn gluten meal - 20.0; swine plasma - 10.0; L-lysine HCL - 4.2; acidifier - 3.0; DL-methionine - 2.4; L-threonine - 1.3; salt - 1.0; flavouring agent - 1.0; choline chloride (60\%) - 0.7; L-tryptophan - 0.1 .

${ }^{5}$ Metabolised energy used as the reference. 
feed. All samples were stored at $-20{ }^{\circ} \mathrm{C}$ until required for analysis. The feed samples were analysed in two replications for their proximate composition (AOAC, 1993).

Pig body weight and feed intake were determined weekly. For the comparative slaughter measurements, another three piglets (WW: $4.85 \pm 1.15 \mathrm{~kg}$ ) from the same weaning group were sacrificed at the beginning of the experiment to estimate the baseline body composition. The 32 male piglets that were kept until the end of the experiment (at day 28) were sacrificed by electric shock and total bleeding after a $12 \mathrm{~h}$ fasting period in which the animals were given only water. All blood was collected in plastic bags and weighed. The following organs were excised, emptied, and weighed: digestive and urinary tracts and respective peripheral glands, reproductive organs, heart, liver, spleen, lungs, kidneys, and perirenal fat. The carcasses, which included the head, feet, hooves, and tail, were cut longitudinally into two halves that were weighed individually. To prevent loss of water content, organs, and blood, as well as the left carcass, were packed into plastic bags and kept refrigerated at $-15{ }^{\circ} \mathrm{C}$ until processing. During processing, each fraction of the experimental material (organs + blood; left carcass) was cut into pieces using an electric saw and the pieces were minced in a 3-HP shredder (EIBEL Ind. Maq., Canoas, RS, Brazil). After homogenization, two representative subsamples of each fraction $(250 \mathrm{~g})$ were collected for chemical analysis. Carcass and blood + organs samples were ground in a ball mill (Model DL-ME, DeLeo Equipamentos Laboratoriais, Porto Alegre, RS, Brazil). Dry matter (DM) was determined by pre-drying the samples in a forced-air oven at $60{ }^{\circ} \mathrm{C}$ until constant weight and subsequent drying at $105{ }^{\circ} \mathrm{C}$ for $12 \mathrm{~h}$ (method: 930.15; AOAC, 1995). Ash was determined by incineration in a muffle furnace at $600{ }^{\circ} \mathrm{C}$ for $2 \mathrm{~h}$ (method: 942.05; AOAC, 1995). Nitrogen content was determined in the dry material according to the Micro-Kjeldhal (method 954.01; AOAC, 1995 adapted by Prates, 2007; model TE 036/2; Tecnal, Piracicaba, SP, Brazil). Crude protein was calculated as nitrogen $\times 6.25$. The gross energy (GE) was determined by pressurised combustion with oxygen in an adiabatic bomb calorimeter (Model C2000 - IKA Werke GmbH \& Co. KG, Staufen, Germany). Benzoic acid (6,318 $\mathrm{kcal} \mathrm{kg}^{-1}$ ) was used as the standard for calibration and was determined to be $6,317 \pm 2 \mathrm{kcal} \mathrm{kg}^{-1}$ at assay. Crude fat was determined after ether extraction (method 920.39; AOAC, 1995 ) in an extractor apparatus. All analyses were performed in duplicate, and the standard error between replicates was less than 5\% for all methods and less than 1\% for energy.

The gain in protein, fat, ash, water and GE was estimated as the daily deposition rate $\left(\mathrm{g} \mathrm{d}^{-1}\right.$ or Mcal d $\left.\mathrm{d}^{-1}\right)$ as follows: (final content in $\mathrm{g}$ or Mcal) - (baseline content in $g$ or Mcal)/number of days of experiment. To calculate nutrient retention, the empty body was defined as the weighted mean of the carcass + organs + blood, without the contents of the gastrointestinal tract. Metabolisable energy daily intake was determined by multiplying feed intake $(\mathrm{kg})$ by the measured ME value $\left(\mathrm{Mcal} \mathrm{kg}^{-1}\right)$, which was calculated by total collection and chemical analysis of faeces and urine from experimental diets. The retained energy as protein (REP) and retained energy as fat (REF) were calculated as protein deposition $\left(\mathrm{g} \mathrm{d}^{-1}\right)$ multiplied by $5.66 \mathrm{kcal} \mathrm{g}^{-1}$, and the fat deposition $\left(\mathrm{g} \mathrm{d}^{-1}\right)$ multiplied by $9.46 \mathrm{kcal} \mathrm{kg}^{-1}$, respectively (Oresanya et al., 2008). The caloric conversion for each experimental period was calculated as total ME intake (Mcal) divided by the total weight gain $(\mathrm{kg})$. The daily heat production was calculated as the difference between the daily ME intake (Mcal d ${ }^{-1}$ ) and the daily energy retention $\left(\mathrm{Mcal} \mathrm{d}^{-1}\right)$. When expressed on the basis of metabolic weight (Mcal d ${ }^{-1}$ per $\mathrm{kg}^{0.75}$ ), total heat production was divided by the sum of the daily metabolic weights of each piglet throughout the experiment. The energy efficiency was measured by dividing REP + REF by the ME intake.

Data were analysed by ANOVA using the Generalized Linear Model (GLM) procedure of SAS (Statistical Analysis System, version 9.2), considering the main effects and the interactions between each of the two factors. Weaning age was included in the model as a covariate. When significance was observed for variances in ME levels, the sum of squares was broken down into linear and quadratic effects. When the ME $\times \mathrm{WW}$ interaction was significant, ME levels were regressed for heavy and light groups and independent intercepts and slopes tested for significance. The cage was the experimental unit for all analyses and the results were considered statistically significant if $\mathrm{P}<0.05$.

\section{Results}

The determined ME concentrations were very close to the expected ME concentrations (Table 1).

There was no significant interaction between dietary $\mathrm{ME}$ and weaning weight for any of the evaluated growth performance responses (Table 2). Average daily feed intake, $\mathrm{ADG}$, and feed conversion ratio (FCR) were not affected by dietary ME concentration, but weaning weight significantly influenced $(\mathrm{P}<0.05) \mathrm{ADFI}, \mathrm{ADG}$, and FCR.

A ME $\times W W$ interaction $(\mathrm{P}<0.05)$ on $\mathrm{DM}$, protein, and GE was observed (Tables 3 and 4). The regression analysis shows that DM was increased, in carcasses of heavy piglets, as $\mathrm{ME}$ increased $(\mathrm{P}<0.05)$. Increasing $\mathrm{ME}$ increased $\mathrm{DM}$ 
Table 2 - Performance of piglets according to dietary metabolisable energy (ME) and weaning weight (WW) during the total period (1 to $28 \mathrm{~d}$ after weaning)

\begin{tabular}{|c|c|c|c|c|c|c|c|c|c|c|c|}
\hline \multirow{2}{*}{ Item } & \multicolumn{5}{|c|}{ ME $\left(\right.$ Mcal kg $\left.{ }^{-1}\right)$} & \multicolumn{3}{|c|}{ WW (kg) } & \multicolumn{3}{|c|}{ P-value } \\
\hline & 3.25 & 3.40 & 3.55 & 3.70 & SEM & 6.3 & 4.0 & SEM & $\mathrm{ME}$ & WW & $\mathrm{ME} \times \mathrm{WW}$ \\
\hline Piglets (n) & 8 & 8 & 8 & 8 & - & 16 & 16 & - & - & - & - \\
\hline $\operatorname{ADFI}(\mathrm{g})$ & 570 & 592 & 581 & 558 & 18 & 600 & 550 & 12 & 0.598 & 0.011 & 0.710 \\
\hline FCR $\left(\mathrm{g} \mathrm{g}^{-1}\right)$ & 1.38 & 1.44 & 1.30 & 1.32 & 0.04 & 1.31 & 1.42 & 0.04 & 0.197 & 0.016 & 0.072 \\
\hline
\end{tabular}

ADFI - average daily feed intake; ADG - average daily gain; FCR - feed conversion ratio.

SEM - standard error of the mean.

Table 3 - Interactions between dietary metabolisable energy (ME) and weaning weight (WW) on body chemical composition and energy use efficiency of piglets ${ }^{1}$

\begin{tabular}{|c|c|c|c|c|c|}
\hline Item & WW (kg) & Equation & RMSE & P-value & $r^{2}$ \\
\hline \multicolumn{6}{|l|}{ Carcass } \\
\hline Dry matter $\left(\mathrm{g} \mathrm{kg}^{-1}\right)$ & $\begin{array}{l}4.0 \\
6.0\end{array}$ & $\begin{array}{l}Y=291-1.50 \times \mathrm{ME} \\
Y=267+15.07 \times \mathrm{ME}\end{array}$ & $\begin{array}{l}19.69 \\
15.40\end{array}$ & $\begin{array}{l}0.798 \\
0.000\end{array}$ & 0.37 \\
\hline Dry matter $\left(\mathrm{g} \mathrm{kg}^{-1}\right)$ & $\begin{array}{l}4.0 \\
6.0\end{array}$ & $\begin{array}{l}Y=281-1.77 \times \mathrm{ME} \\
Y=253+16.13 \times \mathrm{ME}\end{array}$ & $\begin{array}{l}13.99 \\
13.96\end{array}$ & $\begin{array}{l}0.597 \\
0.001\end{array}$ & 0.53 \\
\hline Protein $\left(\mathrm{g} \mathrm{kg}^{-1}\right)$ & $\begin{array}{l}4.0 \\
6.0\end{array}$ & $\begin{array}{l}Y=172-6.21 \times \mathrm{ME} \\
Y=154+2.15 \times \mathrm{ME}\end{array}$ & $\begin{array}{l}8.85 \\
8.22\end{array}$ & $\begin{array}{l}0.007 \\
0.262\end{array}$ & 0.37 \\
\hline Gross energy (Mcal kg ${ }^{-1}$ ) & $\begin{array}{l}4.0 \\
6.0\end{array}$ & $\begin{array}{l}Y=1.65+0.03 \times \mathrm{ME} \\
Y=1.55+0.14 \times \mathrm{ME}\end{array}$ & $\begin{array}{l}0.11 \\
0.12\end{array}$ & $\begin{array}{l}0.199 \\
0.000\end{array}$ & 0.47 \\
\hline Heat production $\left(\mathrm{Mcal} \mathrm{d}^{-1}\right)$ & $\begin{array}{l}4.0 \\
6.0\end{array}$ & $\begin{array}{l}Y=1.00+0.08 \times \mathrm{ME} \\
Y=1.29+0.04 \times \mathrm{ME}\end{array}$ & $\begin{array}{l}0.12 \\
0.13\end{array}$ & $\begin{array}{l}0.006 \\
0.217\end{array}$ & 0.31 \\
\hline
\end{tabular}

RMSE - residual mean square error.

${ }^{1}$ Weaned piglets (19-21 d of age).

${ }^{2}$ Weighted means of carcass and organs + blood (no intestinal content).

Table 4 - Body chemical composition of piglets according to the dietary metabolisable energy (ME) and weaning weight (WW)

\begin{tabular}{|c|c|c|c|c|c|c|c|c|c|c|c|c|}
\hline \multirow{2}{*}{ Item } & \multirow{2}{*}{$\mathrm{ISG}^{1}$} & \multicolumn{5}{|c|}{ ME (Mcal kg $\left.{ }^{-1}\right)$} & \multicolumn{3}{|c|}{ WW (kg) } & \multicolumn{3}{|c|}{ P-value } \\
\hline & & 3.25 & 3.40 & 3.55 & 3.70 & SEM & 6.3 & 4.0 & SEM & $\mathrm{ME}$ & WW & $\mathrm{ME} \times \mathrm{WW}$ \\
\hline Piglets (n) & 3 & 8 & 8 & 8 & 8 & - & 16 & 16 & - & - & - & - \\
\hline Dry matter & 319 & 286 & 293 & 301 & 307 & 6 & 305 & 289 & 5 & 0.161 & 0.019 & 0.051 \\
\hline Protein & 154 & 159 & 157 & 155 & 149 & 3 & 157 & 154 & 2 & 0.210 & 0.393 & 0.111 \\
\hline $\mathrm{Fat}^{2}$ & 124 & 98 & 109 & 119 & 132 & 4 & 121 & 108 & 3 & 0.000 & 0.008 & 0.292 \\
\hline \multicolumn{13}{|l|}{ Organs + blood $\left(\mathrm{g} \mathrm{kg}^{-1}\right)$} \\
\hline Dry matter & 182 & 198 & 201 & 214 & 224 & 7 & 214 & 205 & 5 & 0.055 & 0.179 & 0.066 \\
\hline Protein & 128 & 149 & 147 & 149 & 145 & 7 & 165 & 139 & 5 & 0.083 & 0.001 & 0.771 \\
\hline Fat & 34 & 33 & 37 & 39 & 39 & 3 & 39 & 34 & 2 & 0.466 & 0.076 & 0.212 \\
\hline Ash & 19 & 12.9 & 11.5 & 13.0 & 12.3 & 0.5 & 12.5 & 12.3 & 0.3 & 0.142 & 0.810 & 0.361 \\
\hline Gross energy (Mcal kg ${ }^{-1}$ ) & 1.05 & 1.36 & 1.40 & 1.65 & 1.38 & 0.08 & 1.61 & 1.28 & 0.06 & 0.055 & 0.000 & 0.703 \\
\hline Ash & 35 & 25.2 & 23.2 & 24.3 & 23.9 & 0.6 & 24.3 & 24.0 & 0.4 & 0.124 & 0.633 & 0.912 \\
\hline Gross energy (Mcal kg ${ }^{-1}$ ) & 1.81 & 1.69 & 1.77 & 1.86 & 1.94 & 0.04 & 1.89 & 1.74 & 0.03 & 0.001 & 0.001 & 0.028 \\
\hline
\end{tabular}

SEM - standard error of the mean.

${ }^{1}$ Data of the initial slaughter group (ISG; $\mathrm{n}=3$ ) were used to estimate the initial body composition of the experimental pigs and were not included in the statistical analysis. Body weight at slaughter was $4.85 \pm 1.15 \mathrm{~kg}$ (mean \pm standard deviation).

${ }^{2}$ Linear effect on carcass: Fat $=86+11.46 \times \mathrm{ME}\left(\mathrm{P}<0.05, \mathrm{r}^{2}=0.46\right)$; Gross energy $=1.72+0.09 \times \mathrm{ME}\left(\mathrm{P}<0.05, \mathrm{r}^{2}=0.28\right)$.

${ }^{3}$ Weighted mean of carcass and organs + blood (no intestinal content).

${ }^{4}$ Linear effect on empty body: Fat $=74+9.93 \times \mathrm{ME}\left(\mathrm{P}<0.05, \mathrm{r}^{2}=0.43\right)$. 
and GE in empty bodies of heavy piglets $(\mathrm{P}<0.05)$, but not in light piglets. Furthermore, increasing dietary ME levels decreased protein in empty bodies, but only in light piglets $(\mathrm{P}<0.05)$. Increasing dietary ME levels linearly increased fat and GE in carcasses $(\mathrm{P}<0.05)$ and fat in empty bodies (Table 4; $\mathrm{P}<0.05$ ). Heavier weaned piglets showed higher fat $(10.7 \%)$ and GE (7.5\%) in carcasses, protein (15.7\%) and GE $(20.5 \%)$ in organs + blood, and fat $(13.2 \%)$ in empty bodies (Table 4; $\mathrm{P}<0.05$ ).

There was no significant interaction between dietary $\mathrm{ME}$ and weaning weight on daily nutrient deposition rate in empty bodies (Table 5). Increasing dietary ME levels linearly $(\mathrm{P}<0.05)$ increased the fat:protein deposition, total retained energy (RE), RE per unit of $\mathrm{LW}^{0.75}, \mathrm{RE}$ as fat, and $\mathrm{RE}$ as protein and fat in relation to total RE in empty bodies (Table 5). Heavier weaned piglets showed greater DM $(19.7 \%)$, water $(15.6 \%)$, protein $(10.9 \%)$, fat $(17.8 \%)$, ash (17.8\%), RE as protein (19.8\%), and RE as fat (17.9\%) in empty bodies (Table 5; $\mathrm{P}<0.05$ ).
A ME $\times W W$ interaction $(\mathrm{P}<0.05)$ on heat production was observed. The interaction was illustrated by an increasing heat production in light piglets $(\mathrm{P}<0.05)$ as dietary ME levels increased (Tables 3 and 6). The same response was not observed in heavy weaned piglets. Metabolisable energy intake and caloric conversion (expressed as Mcal energy intake $\mathrm{kg}^{-1} \mathrm{WG}$ ) were increased with increased dietary ME levels (Table 6; $\mathrm{P}<0.05$ ). Heavier weaned piglets had greater ME intake $(7.3 \%)$ and energy efficiency (12.4\%) and lower ADFI per $\mathrm{kg}$ of $\mathrm{LW}^{0.75}$ $(10.0 \%)$ and heat production per $\mathrm{kg}$ of $\mathrm{LW}^{0.75}(20.8 \%)$ (Table 6; $\mathrm{P}<0.05$ ).

\section{Discussion}

The current study investigated the interaction of ME concentration and weaning weight under the hypothesis that light piglets at weaning fed a diet with high energy concentration would show compensatory growth relative

Table 5 - Daily nutrient deposition rates on empty body of piglets according to the dietary metabolisable energy (ME) and weaning weight (WW)

\begin{tabular}{|c|c|c|c|c|c|c|c|c|c|c|c|}
\hline \multirow{2}{*}{ Deposition rate } & \multicolumn{5}{|c|}{$\mathrm{ME}\left(\mathrm{Mcal} \mathrm{kg}{ }^{-1}\right)$} & \multicolumn{3}{|c|}{ WW (kg) } & \multicolumn{3}{|c|}{ P-value } \\
\hline & 3.25 & 3.40 & 3.55 & 3.70 & SEM & 6.3 & 4.0 & SEM & ME & WW & $\mathrm{ME} \times \mathrm{WW}$ \\
\hline Piglets (n) & 8 & 8 & 8 & 8 & - & 16 & 16 & - & - & - & - \\
\hline \multicolumn{12}{|l|}{ Empty body } \\
\hline Dry matter $\left(\mathrm{g} \mathrm{d}^{-1}\right)$ & 108 & 113 & 129 & 127 & 7 & 132 & 106 & 5 & 0.174 & 0.003 & 0.312 \\
\hline Water $\left(\mathrm{g} \mathrm{d}^{-1}\right)$ & 286 & 286 & 302 & 283 & 15 & 314 & 265 & 11 & 0.810 & 0.003 & 0.379 \\
\hline Protein $\left(\mathrm{g} \mathrm{d}^{-1}\right)$ & 64.8 & 63.8 & 70.1 & 64.1 & 4.0 & 72.9 & 58.4 & 2.8 & 0.659 & 0.001 & 0.560 \\
\hline $\mathrm{Fat}^{1}\left(\mathrm{~g} \mathrm{~d}^{-1}\right)$ & 31.8 & 39.2 & 47.0 & 52.3 & 3.8 & 46.7 & 38.4 & 2.7 & 0.005 & 0.043 & 0.343 \\
\hline $\operatorname{Ash}\left(\mathrm{g} \mathrm{d}^{-1}\right)$ & 9.4 & 8.5 & 9.9 & 9.0 & 0.7 & 10.1 & 8.3 & 0.5 & 0.498 & 0.018 & 0.918 \\
\hline Fat:PD ${ }^{1}$ & 0.496 & 0.611 & 0.665 & 0.813 & 0.036 & 0.635 & 0.658 & 0.025 & 0.000 & 0.531 & 0.585 \\
\hline Ash:PD & 0.145 & 0.133 & 0.143 & 0.144 & 0.005 & 0.14 & 0.142 & 0.004 & 0.414 & 0.616 & 0.290 \\
\hline $\operatorname{RE}^{1}\left(\mathrm{kcal} \mathrm{d}^{-1}\right)$ & 652 & 721 & 835 & 844 & 55 & 846 & 680 & 39 & 0.006 & 0.061 & 0.389 \\
\hline $\mathrm{RE}^{1,2}\left(\mathrm{kcal} \mathrm{d}^{-1} \mathrm{~kg}^{0.75}\right)$ & 116 & 128 & 140 & 148 & 6 & 126 & 125 & 4 & 0.017 & 0.894 & 0.234 \\
\hline RE protein $\left(\mathrm{kcal} \mathrm{d}^{-1}\right)$ & 367 & 361 & 397 & 363 & 22 & 413 & 331 & 16 & 0.659 & 0.001 & 0.560 \\
\hline $\mathrm{RE} \mathrm{fat}^{1}\left(\mathrm{kcal} \mathrm{d}^{-1}\right)$ & 300 & 371 & 445 & 495 & 36 & 442 & 363 & 26 & 0.005 & 0.043 & 0.343 \\
\hline RE protein ${ }^{1}(\%$ of RE) & 55.4 & 49.7 & 47.9 & 42.6 & 2.0 & 49.4 & 50.1 & 1.4 & 0.000 & 0.711 & 0.558 \\
\hline RE fat ${ }^{1}(\%$ of RE) & 44.7 & 50.3 & 52.5 & 57.4 & 1.4 & 51.2 & 52.9 & 1.0 & 0.000 & 0.255 & 0.443 \\
\hline
\end{tabular}

Fat:PD - fat:protein deposition; RE - retained energy; RE protein - retained energy as protein; RE fat - retained energy as fat; SEM - standard error of the mean.

${ }^{1}$ Linear effect: Fat $=-78.53+0.03 \times \mathrm{ME}\left(\mathrm{P}<0.000, \mathrm{R}^{2}=0.54\right)$; Fat: $\mathrm{PD}=-1.18+0.001 \times \mathrm{ME}\left(\mathrm{P}<0.000, \mathrm{R}^{2}=0.84\right) ; \mathrm{RE}=-422.92+0.34 \times \mathrm{ME}\left(\mathrm{P}<0.007, \mathrm{R}^{2}=0.52\right) ; \mathrm{RE}$ per unit metabolic weight $=-8.491+0.040 \times \mathrm{ME}\left(\mathrm{P}<0.010, \mathrm{R}^{2}=0.20\right) ; \mathrm{RE}$ fat $=-742.73+0.33 \times \mathrm{ME}\left(\mathrm{P}<0.000, \mathrm{R}^{2}=0.54\right) ; \mathrm{RE}$ protein $(\% \mathrm{RE})=101.36-0.02 \times \mathrm{ME}\left(\mathrm{P}<0.001, \mathrm{R}^{2}=0.37\right)$ as fat $=-1.36+0.017 \times \mathrm{ME}\left(\mathrm{P}<0.000, \mathrm{R}^{2}=0.38\right)$

${ }^{2}$ Retained energy per unit of metabolic weight.

Table 6 - Energy use efficiency of piglets according to the dietary metabolisable energy (ME) and weaning weight (WW)

\begin{tabular}{|c|c|c|c|c|c|c|c|c|c|c|c|}
\hline \multirow{2}{*}{ Item } & \multicolumn{5}{|c|}{ ME $\left(\right.$ Mcal kg $\left.{ }^{-1}\right)$} & \multicolumn{3}{|c|}{ WW (kg) } & \multicolumn{3}{|c|}{ P-value } \\
\hline & 3.25 & 3.40 & 3.55 & 3.70 & SEM & 6.3 & 4.0 & SEM & $\mathrm{ME}$ & WW & $\mathrm{ME} \times \mathrm{WW}$ \\
\hline Piglets (n) & 8 & 8 & 8 & 8 & - & 16 & 16 & - & - & - & - \\
\hline ME intake $^{1}\left(\right.$ Mcal d $\left.^{-1}\right)$ & 1.79 & 1.97 & 2.04 & 2.07 & 0.06 & 2.04 & 1.89 & 0.04 & 0.014 & 0.021 & 0.854 \\
\hline Caloric conversion $^{1}$ (Mcal ME kg WG ${ }^{-1}$ ) & 4.45 & 4.82 & 4.66 & 5.00 & 0.06 & 4.77 & 4.70 & 0.04 & 0.000 & 0.269 & 0.615 \\
\hline Heat production $\left(\mathrm{Mcal} \mathrm{d}^{-1}\right)$ & 1.13 & 1.25 & 1.20 & 1.23 & 0.04 & 1.19 & 1.21 & 0.03 & 0.322 & 0.707 & 0.033 \\
\hline Heat production (Mcal d $\mathrm{d}^{-1} \mathrm{~kg}^{0.75}$ ) & 0.20 & 0.23 & 0.21 & 0.22 & 0.01 & 0.19 & 0.24 & 0.08 & 0.373 & 0.000 & 0.086 \\
\hline
\end{tabular}

SEM - standard error of the mean; WG - weight gain.

${ }^{1}$ Linear effect: $\mathrm{ME}$ intake $=0.68+0.365 \times \mathrm{ME}\left(\mathrm{P}<0.020, \mathrm{R}^{2}=0.17\right)$; Caloric conversion $=1.47+0.928 \times \mathrm{ME}\left(\mathrm{P}<0.001 ; \mathrm{R}^{2}=0.69\right)$ 
to heavy piglets because of their limited capacity of gastrointestinal tract or a specific energy requirement. However, the results of the experiment refute the hypothesis, as shown by the absence of interaction between the factors for all evaluated growth performance responses. The ME did not affect ADG or ADFI, similar to the data obtained by Oresanya et al. (2008) and Vieira et al. (2015), who worked with weaned piglets. Feed conversion ratio also showed no difference according to ME level, agreeing with the results obtained by Trindade Neto et al. (2003). As indicated by Henry (1985) and Kyriazakis and Emmans (1992), when energy is not the first limiting resource, feed intake will be modulated to meet the first limiting nutrient. For instance, the amino acid:energy ratio around the optimum level for growth will influence feed intake. The deficiency in the limiting amino acid or protein supply results in a compensatory increase in feed intake to meet the requirements. In the present study, the Lys:ME ratio was not maintained constant as ME increased (Pre-starter: 4.46 to $3.92 \mathrm{~g} \mathrm{Mcal}^{-1}$, and Starter: 3.81 to $3.35 \mathrm{~g} \mathrm{Mcal}^{-1}$ ); therefore, one would expect an increase in ADFI to reach the lysine (lys) requirements. It is possible that the lower lys:ME ratio was enough to meet the requirements of the weaned piglets, in the present study, and avoid an increase in ADFI. Vieira et al. (2015) showed that the level of 3.4 Mcal kg-1 of ME and 4.14 and $3.91 \mathrm{~g} \mathrm{Mcal}^{-1}$ lysine, in the pre-starter and starter periods, respectively, was sufficient to allow piglet growth after weaning.

On the other hand, WW significantly influenced growth performance, as heavy animals presented better FCR and greater ADFI (15\%) and ADG (8\%) compared with light animals $(\mathrm{P}<0.05)$. The better FCR indicates that the greater ADG of heavy piglets was not achieved only because of their greater physical capacity to consume more feed. Pardo et al. (2013) confirmed the relationship between growth rate and weaning weight depending on birth weight, and showed that lighter pigs took more days than the heavier pigs to reach market weight.

In the present study, an interaction between ME and WW showed that heavy piglets increase carcass DM as ME increases, probably due to the higher fat content observed in this fraction. The linear increase in fat content also resulted in a linear increase in GE in the carcass. The concentration of protein in the carcass, however, was not affected by any of the studied factors. The absence of effect of ME levels in organ + blood is consistent with previous studies (Oresanya et al., 2007; Vieira et al al., 2015). Heavier piglets, however, had greater protein and GE in organ + blood, which is consistent with their greater live weight. An interaction between ME and WW showed an increase in $\mathrm{DM}$ and GE as ME increases in empty body, only in heavy piglets. As observed in the carcass, these results were probably due to the greater fat content in the empty bodies of heavy weaned pigs. By contrast, only light piglets responded negatively for protein content in the empty body as a result of the increasing ME of the diet. Little is known about the interactive effects of dietary energy concentration and weaning weight on the chemical composition of the body of the weaned pig. A previous study by Oresanya et al. (2008) reported a reduction of protein in the empty body with increasing dietary energy levels, without any effect on the carcass or organ + blood. Vieira et al. (2015), however, did not find any effect of ME or WW on the chemical body composition of weaned pigs.

The lack of effect of the factors on ash:protein deposition ratio, which remained almost constant in response to the two assessed factors, indicates that the growth of muscle mass was appropriate in relation to bone growth, independently of the investigated factors. The greater daily body nutrient deposition rate found in heavy piglets is in accordance with the greater ADG observed in these animals. On the other hand, ME in the diet did not influence deposition rates of $\mathrm{DM}$, water, protein or ash, though it affected the fat and energy deposition rates. Piglets that were given the greatest ME levels had greater fat and energy deposition rates in the empty body. The greatest contribution for this gain came from the carcass, and not the organs, which demonstrates that subcutaneous fat deposition affects these responses more intensely. This fact also explains the absence of any improvement in growth performance related to ME increase, which is linked to the weight gain of lean tissue being associated with water deposition (Quiniou et al., 1996).

Quiniou and Noblet (2012) confirmed the ability of growing pigs to adjust their voluntary feed intake to the dietary energy concentration, similar to the results obtained by Beaulieu et al. (2006), who found a negative linear effect for feed intake between 3.35 and $3.65 \mathrm{Mcal} / \mathrm{kg}$ of digestible energy levels. However, in our experiment with animals younger than those evaluated in the afore-mentioned studies, piglets fed the highest energy diets ingested larger energy contents. It may be hypothesised that weaned piglets are unable to control energy intake because these animals suffer from an energy deficit, proportional to the growth potential (Oresanya, 2005).

In the present experiment, the extra energy consumed, without any corresponding increase in dietary protein, did not change the protein deposition rate, and resulted solely in fat deposition. Similar results were observed by Oresanya et al. (2008). According to $\mathrm{Gu}$ and $\mathrm{Li}$ (2003), the capacity of the liver tissue of a piglet to perform $\beta$-oxidation is low; 
therefore, it is more expressively inclined to performing esterification of fatty acids that circulate in blood. This benefits the storing of fat in the adipose tissue when excess energy is available, as observed in the present experiment. An increase of $36 \%$ in fat deposition in the empty bodies of piglets was observed when the extreme ME contents were compared (3.25 vs. $3.70 \mathrm{Mcal} \mathrm{ME} / \mathrm{kg}$ ). The fat:protein deposition ratio was significantly affected by $\mathrm{ME}$ and also the caloric conversion. Considering the greater water content of the lean tissue (80\%) compared with the fatty tissue $(15 \%)$, lower energy levels per gram of gain are required by the former ( $1.12 \mathrm{vs.} 7.83 \mathrm{kcal}$, for the lean and fatty tissues, respectively; Collin et al., 2001). This also may explain why the increase in ME did not improve feed conversion ratio, as its main effect was observed in body fat gain. A $60 \%$ increase in the fat:protein deposition ratio was observed between the two extreme ME levels used. Souza et al. (2000) observed a 20\% increase in the fat:protein deposition ratio for weaned piglets that were given diets containing 3.24 to $3.59 \mathrm{Mcal} \mathrm{ME} / \mathrm{kg}$.

Piglets with greater ME were less efficient in caloric conversion, which is in contrast to the result obtained by Rezende et al. (2006), who observed no effect of energy level on caloric conversion in barrows in the finishing phase. This difference may be explained because the latter kept a constant ratio of digestible lysine and ME. In response to increasing ME, light piglets produced more heat but there was no effect on energy retention. Conversely, heavy piglets exhibited no change in heat production with increased ME, but were more efficient because they retained more fat. In summary, heavy piglets responded positively to the increase in energy, in contrast to the light piglets. Light piglets may have increased maintenance requirements, because they were more active and presented greater ADFI when expressed using a metabolic weight basis compared with heavy piglets. Studies have shown that maintenance energy increases as the level of ADFI increases, which is due to the digestion process (Labussière et al., 2011; Hu et al., 2012). These results lead to the need for further research to clarify whether there are benefits to accumulate more body fat in the performance immediately after weaning and what are the physiological and behavioural reasons that prevent light piglets from accumulating body fat with increasing ME in the diet.

\section{Conclusions}

The lack of an interaction effect between weaning weight and dietary metabolisable energy content on growth performance does not support the hypothesis that light piglets at weaning do not exhibit compensatory growth because of limitations in energy intake. Heavier weaning weight positively affects weight gain and body nutrient retention, especially body fat deposition. The metabolisable energy level of $3.40 \mathrm{Mcal} \mathrm{kg}^{-1}$ is enough to allow piglet growth after weaning, regardless of weaning weight.

\section{References}

AOAC - Association of Official Analytical Chemistry. 1993. Official methods of analysis. 4th ed. AOAC International, Washington, DC.

AOAC - Association of Official Analytical Chemists. 1995. Official methods of analysis. 15th ed. AOAC International, Arlington, VA.

Beaulieu, A. D.; Levesque, C. L. and Patience, J. F. 2006. The effects of dietary energy concentration and weaning site on weanling pig performance. Journal of Animal Science 84:1159-1168.

Beaulieu, A. D.; Aalhus, J. L.; Williams, N. H. and Patience, J. F. 2010. Impact of piglet birth weight, birth order, and litter size on subsequent growth performance, carcass quality, muscle composition, and eating quality pork. Journal of Animal Science 88:2767-2778.

Bérard, J.; Kreuzer, M. and Bee, G. 2008. Effect of litter size and birth weight on growth, carcass and pork quality, and their relationship to post mortem proteolysis. Journal of Animal Science $86: 2357-2368$.

Campbell, R. G. 1987. Energy and protein metabolism in the pig. In: Manipulating pig production. Barnett, J. L., ed. Australian Pig Science Association, Werribee, Australia.

Collin, A.; van Milgen, J.; Dubois, S. and Noblet, J. 2001. Effect of high temperature and feeding level on energy utilization in piglets. Journal of Animal Science 79:1849-1857.

Fix, J. S.; Cassady, J. P.; Holl, J. W.; Herring, W. O.; Culbertson, M. S. and See, M. T. 2010. Effect of piglet birth weight on survival and quality of commercial market swine. Livestock Science 132:98-106.

$\mathrm{Gu}, \mathrm{X}$. and Li, D. 2003. Fat nutrition and metabolism in piglets: a review. Animal Feed Science and Technology 109:151-170.

Hu, Q.; Wang, F. L.; Piao, X. S.; Ni, J. J.; Zhang, X. M. and Li, D. F. 2012. Effects of fasting duration and body weight on fasting heat production in growing pigs. Journal of Animal and Veterinary Advances 11:2333-2341.

Henry, Y. 1985. Dietary factors involves in feed intake regulation in growing pigs: A review. Livestock Production Science 12:339-354.

Kyriazakis, I. and Emmans, G. C. 1992. The effects of varying protein and energy intakes on the growth and body composition of pigs. 1. The effects of energy intake at constant, high protein intake. British Journal of Nutrition 68:603-613.

Labussière, E.; van Milgen, J.; de Lange, C. F. M. and Noblet, J. 2011. Maintenance energy requirements of growing pigs and calves are influenced by feeding level. Journal of Nutrition 141:1855-1861.

Oresanya, T. F. 2005. Energy metabolism in the weanling pig: effects of energy concentration and intake on growth, body composition and nutrient accretion in the empty body. Thesis (Ph.D). University of Saskatchewan, Saskatoon, Saskatchewan, Canada.

Oresanya, T. F.; Beaulieu, A. D.; Beltranema, E. and Patience, J. F. 2007. The effect of dietary energy concentration and total lysine/ digestible energy ratio on the growth performance of weaned pigs. Canadian Journal of Animal Science 87:45-55.

Oresanya, T. F.; Beaulieu, A. D.; and Patience, J. F. 2008. Investigations of energy metabolism in weanling barrows: The interaction of dietary energy concentration and daily feed (energy) intake. Journal of Animal Science 86:348-363. 
Pardo, C. E.; Kreuzer, M. and Bee, G. 2013. Effect of average litter weight in pigs on growth performance, carcass characteristics and meat quality of the offspring as de pending on birth weight. Animal 7:1884-1892.

Prates, E.R. 2007. Techniques of research in animal nutrition. UFRGS, Porto Alegre.

Quiniou, N.; Dourmad, J. Y. and Noblet, J. 1996. Effect of energy intake on the performance of different types of pig from 45 to $100 \mathrm{~kg}$ body weight. 1. Protein and lipid deposition. Animal Science 63:277-288.

Quiniou, N.; Dubois, S. and Noblet, J. 2000. Voluntary feed intake and feeding behaviour of group-housed growing pigs are affected by ambient temperature and body weight. Livestock Production Science 63:245-253.

Quiniou, N. and Noblet, J. 2012. Effect of the dietary net energy concentration on feed intake and performance of growingfinishing pigs housed individually. Journal of Animal Science 90:4362-4372.

Rezende, W. O.; Donzele, J. L.; Oliveira, R. F. M.; Abreu, M. L. T.; Ferreira, A. S.; Silva, F. C. O. and Apolônio, L. R. 2006. Níveis de energia metabolizável mantendo a relação lisina digestível:caloria em rações para suínos machos castrados em terminação. Revista Brasileira de Zootecnia 35:1101-1106.

Rostagno, H. S.; Albino, L. F. T.; Donzele, J. L.; Gomes, P. C.; Oliveira, R. F.; Lopes, D. C.; Ferreira, A. S.; Barreto, S. L. T. and Euclides,
R. F. 2005. Tabelas brasileiras para aves e suínos: composição de alimentos e exigências nutricionais. 2.ed. Universidade Federal de Viçosa, Viçosa, MG.

Souza, T. C. R.; Aumaitre, A.; Mourot, J. and Peiniau, J. 2000. Effect of graded levels of tallow in the diet on performance, digestibility of fat, lipogenesis and body lipid deposition of the weaned piglets. Asian-Australasian Journal of Animal Science 13:497-505.

Trindade Neto, M. A.; Barbosa, H. P.; Petelincar, I. M. and Schammass, E. A. 2003. Effect of manufacturing and protein level in diets with corn and soybean on performance of weaned piglets. Pesquisa Agropecuária Brasileira 38:427-435.

Trindade Neto, M. A.; Berto, D. A.; Nyachoti, C. M. and Schammass, E. A. 2010. Energy and amino acid content in phase 1 nursery diet: piglet performance and body chemical composition. Revista Brasileira de Zootecnia 39:1286-1294.

Van Lunen, T. A. and Cole, D. J. A. 1998. The effect of dietary energy concentration and lysine/digestible energy ratio on growth performance and nitrogen deposition of young hybrid pigs. Animal Science 67:117-129.

Vieira, M. S.; Ribeiro, A. M. L.; Kessler, A. M.; Chiba, L. I.; Bockor, L. 2015. Performance and body composition of light and heavy early-weaning piglets subject to different dietary energy levels. Livestock Science 178:272-278.

Whittemore, C. T. 1983. Development of recommended energy and protein allowances for growing pigs. Agricultural System 11:159-186. 